\title{
Ecotourism Strategy in Facing the New-Normal Era (Case Study: Ecowisata Gunung Anyar)
}

\author{
Wiwik Dwi Susanti*, Muchlisiniyati Safeyah, Fairuz Mutia \\ Architecture, Faculty of Architecture and Design, Universitas Pembangunan Nasional "Veteran" \\ Jawa Timur, Indonesia
}

${ }^{*}$ Corresponding author:

E-mail: wiwikds.ar@upnjatim.ac.id

\begin{abstract}
The COVID-19 pandemic has changed all aspects of life including people's habits of travelingand traveling. People limit themselves to mobilization to avoid spreading the virus. But that does not mean tourist attractions do not have the opportunity to rise again during the new normalera. According to the Director of the Indonesia Ecotourism Network, Ary Suhandi, in the newnormal era, the trend of large numbers of tourism (mass tourism) is predicted to be replaced bythe trend of quality tourism. "Ecotourism, adventure, and wellness tourism are great opportunities (travel.detik.com). So, that serious effort is needed by ecotourism managers totake advantage of these opportunities. The strategy carried out by the management must continue to prioritize the principles of health protocol handling covid 19. So that will provide comfort for visitors and managers. Ecotourism Gunung Anyar is one of the ecotourism in the East of Surabaya City which is back active in the new normal era. Various kinds of strategies are carried out by ecotourism Gunung Anyar to survive during the COVID-19 pandemic conditions. discussing Gunung Anyar's ecotourism strategy in facing the new normalera but still prioritizing the concept of conservation and education. This study uses qualitativeand quantitative methods. Based on the results of the study it can be concluded that the strategycarried out includes internal and external strategies. The manager's efforts to continue to prioritize the concept of conservation, while externally are related to service strategies to visitors during the new normal.
\end{abstract}

Keywords: Ecowisata Gunung Anyar, new normal era, external strategy, internal strategy

\section{Introduction}

At this time the whole world is faced with cases of the spread of the Coronavirus outbreak.The rapid spread of the coronavirus has an impact on all aspects of life. Corona is even the only virus that has successfully captured the attention of the World Health Organization (WHO) and declared it a global pandemic. Global problems arise because they have an impact on all sectors of life, namely the economic, education, social, tourism and so on. Based on thefacts about the dangers and risks due to COVID-19, it creates a sense of fear. So that it has animpact on the sense of concern for the community to carry out all its activities that have the possibility of contracting the COVID19 virus. PSBB (Large-Scale Social Restrictions), is implemented in several big cities in Indonesia as an effort to suppress the spread of the coronavirus. The program has an impact on all aspects of life including the condition of the country. So that President Joko Widodo, after almost three months of concentrating on controlling the spread of the virus with PSBB, tried to apply the new normal concept so that a few problems could be resolved. Tourism is one of the aspects affected by the PSBB so many tourist attractions are closed due to the lack of visitors (Candra \& Rekha, 2020). New normal provides hope in the developmentof tourist attractions. It is even predicted

How to cite:

Susanti, W. D., Safeyah, M., \& Mutia, F. (2021). Ecotourism strategy in facing the new-normal era (Case Study: Ecowisata Gunung Anyar). $5^{\text {th }}$ International Seminar of Research Month 2020. NST Proceedings. pages 448-453. doi: 10.11594/ nstp.2021.0965 
that the ecotourism area is one of the areas that are in great demand by the community. "We predict that nature-based or outdoor tourism activities will rebound the fastest because ecotourism is not mass tourism but special interest tourism. Wesupport the return or even the development of ecotourism in Indonesia. In the future, we will concentrate on Ecotourism and Wellness Tourism, "said Rizki in his official statement on Friday (22/5/2020). Ecotourism, Adventure Tourism, and Wellness Tourism are expected to bethe most popular products after the Covid-19 pandemic, especially for activities with small andactive groups such as outdoor interactions, nature education activities for families, to activities that contribute to nature conservation. (https://traveling.bisnis.com/).

The Gunung Anyar Mangrove Ecotourism Area is one of the tourist areas in East Surabayawhich is also affected by the coronavirus. One of the efforts made by the manager was to closefor 3 months to suppress the spread of the virus. This study seeks to discuss the efforts of Gunung Anyar ecotourism in facing the current corona pandemic (Lubis \& Wahyudi, 2019).

\section{Material and Methods}

The method used in this research is qualitative research. According to Sugiyono (2017) states that "The qualitative research method is a research method based on the philosophy of postpositivism or interpretive, used to examine the condition of natural objects, where the researcher is the key instrument, the data collection technique is done by triangulation(combination of observation, interviews, documentation), the data obtained tends to be qualitative, the data analysis is inductive/qualitative, and the results of the research are to understand the meaning, understand the uniqueness, construct phenomena, and find hypotheses ".

\section{Method of collecting data}

Primary data collection method by making direct observations at the research location. The observation was emphasized elements related to the health protocol for handling Covid 19.The observation stage was that the researcher went directly to the research location of the Gunung Anyar ecotourism area to get direct and comprehensive data and describe the atmosphere there. In addition, secondary data collection is carried out by browsing the libraryrelated to the Covid 19 handling protocol.

\section{Data analysis method}

Data analysis is carried out based on the theoretical framework of several experts to obtain factual data in the field. Analysis in the form of elements of the Covid 19 health protocol basedon the decree of the Minister of Health of the Republic of Indonesia Number HK.01.07 / MENKES/ $382 / 2020$. The analysis method uses descriptive analysis

\section{Results and Discussion \\ Description of the research location}

Surabaya City Government has opened new tourism in the east coast area Surabaya, precisely in Gunung Anyar District, which is named Wisata Anyar Mangrove (WAM). As an area that is used as an alternative tourist spot in the city of Surabaya, of course, the potential and conditions that exist today must be examined and developed continuously / sustainably without destroying the forest environment mangroves. (Trisbiantoro et al., 2020) Gunung Anyar ecotourism is a tourist attraction in East Surabaya Pamurbaya (Surabaya East Coast) which is located close to a conservation area declared by the Surabaya City Government. So that ecotourism values are applied to support conservation areas. Currently, the Mangrove area in Gunung Anyar is still under development with the construction of several supporting facilities.However, even though it is still in the development stage, it seems that many visitors have come to this location. This tourist attraction has an exotic value, including because it uses an original fishing boat to go to the mangrove area. in 
this place, once we enter the mangrove area,we only see mangrove forests and the sea, which are equipped with interesting flora and fauna (Umasugi et al., 2017).

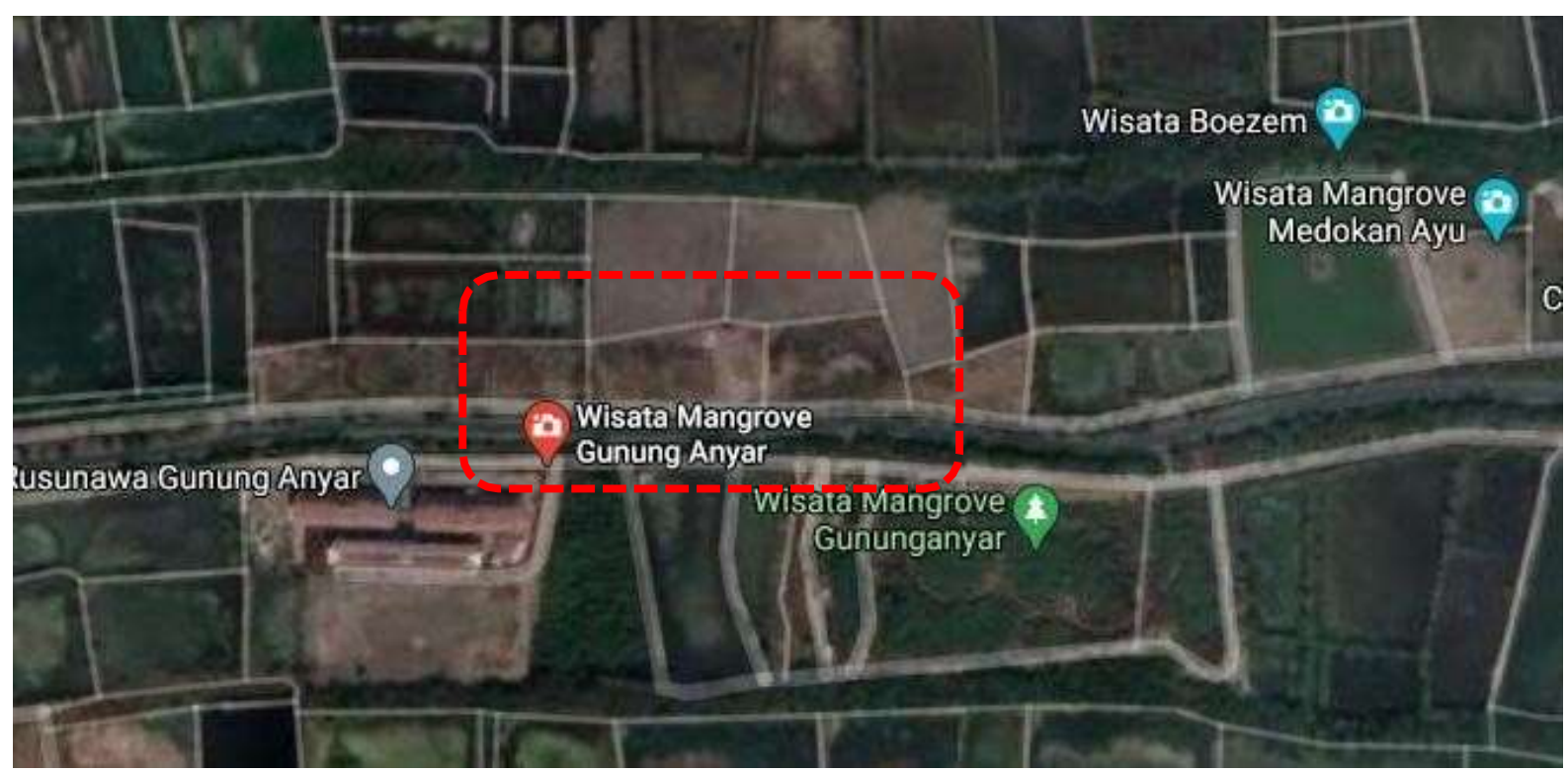

Figure 1. Research location

The Gunung Anyar ecotourism area uses a lot of natural materials and some even use used materials that are no longer used, so this ecotourism seeks to be sustainable in its use and maintenance.
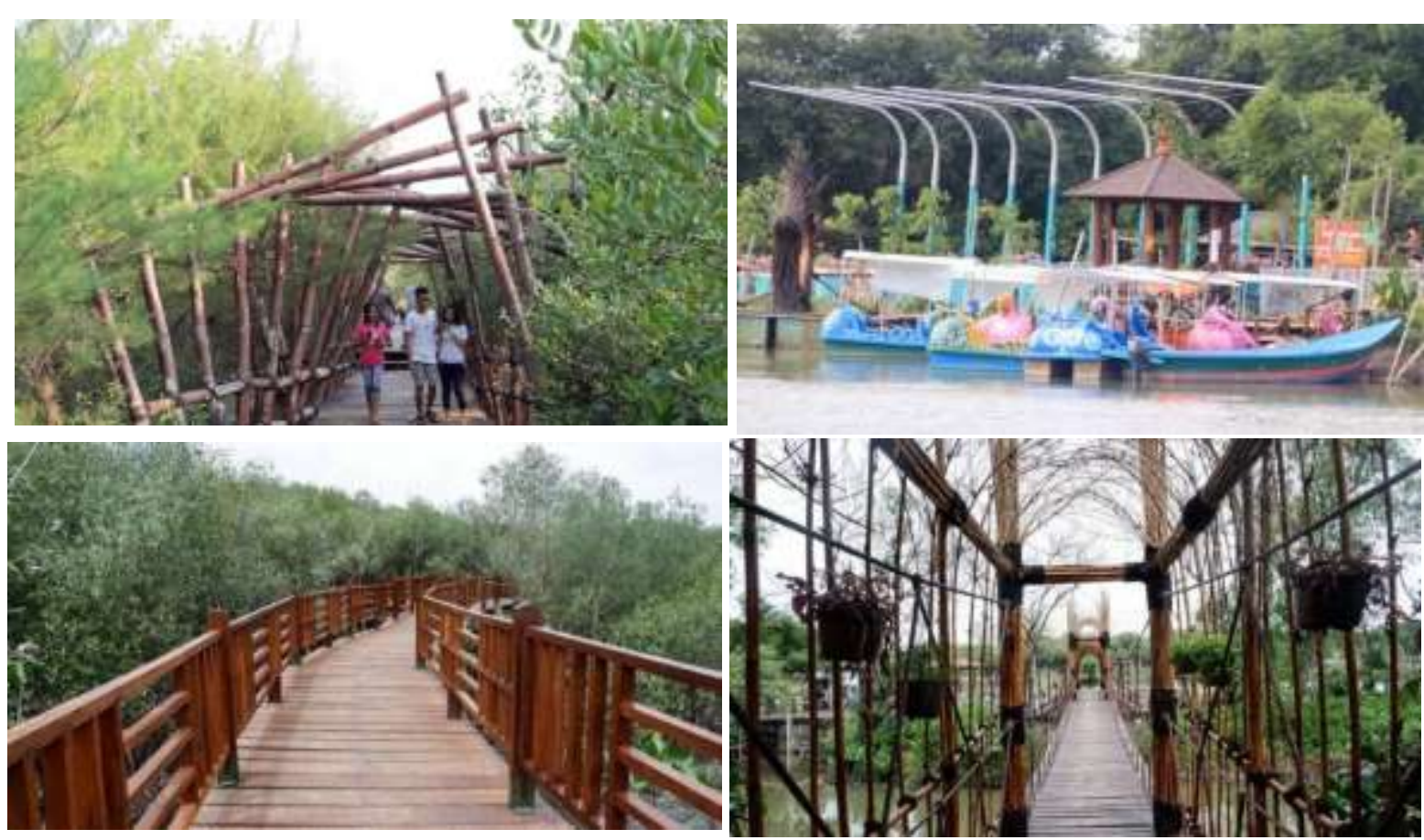

Figure 2. Gunung Anyar ecotourism 


\section{Covid 19 handling strategies in Gunung Anyar Ecotourism}

The strategy carried out by the Gunung Anyar ecotourism manager includes an inward andoutward strategy according to the health protocol passed through KMK Number HK.01.07 / Menkes / 382/2020 regarding health protocols in public places. The internal strategy is to strengthen the management of employees. While strengthening the exit is related to policies that regulate visitors to adhere to the standard covid-19 health protocol by conducting simulations, then socializing and publishing.

The external strategy (for managers) is:

1. Perform cleaning with disinfection periodically (once a day), especially in areas, facilities, and equipment that are shared such as handrails, toilet doors, equipment and equipment for organizing tourist attraction activities, and other public facilities.

2. Provide adequate handwashing facilities with soap which are located close to areas frequented by visitors.

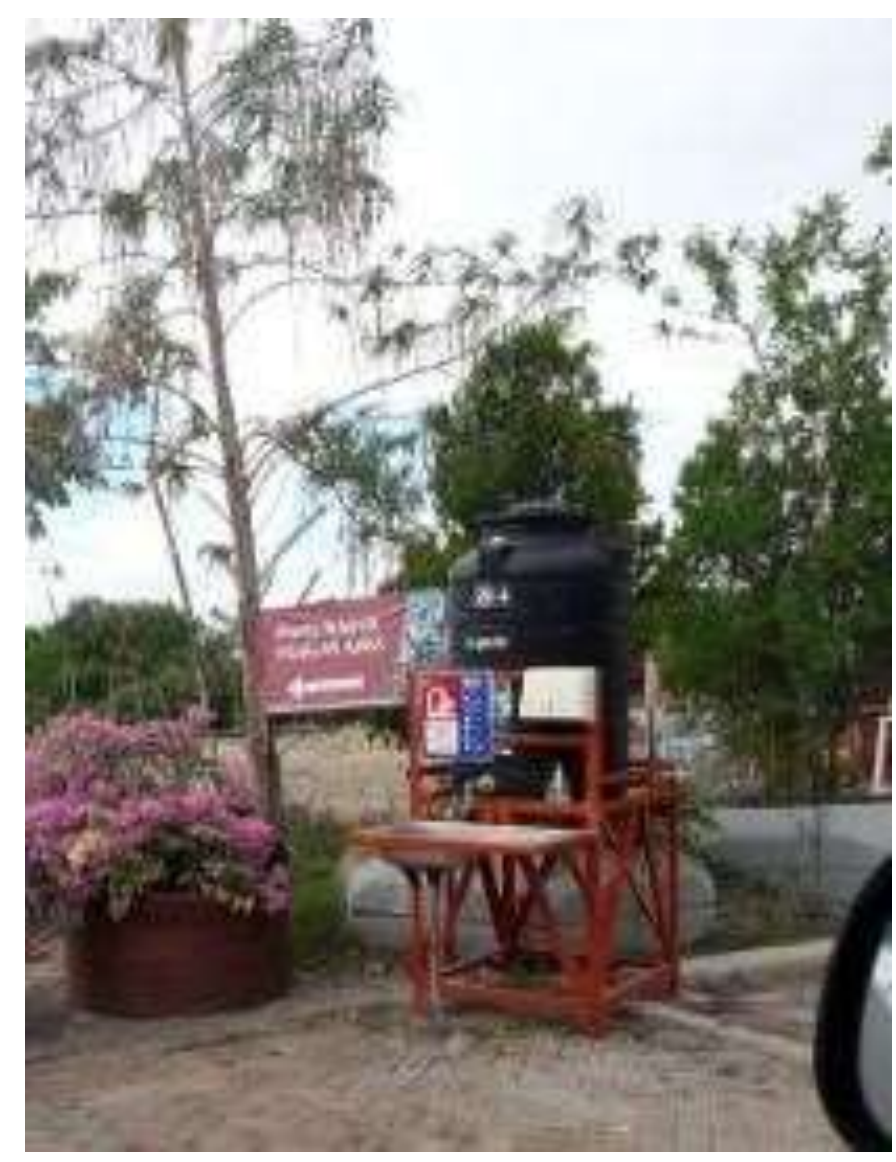

Figure 3. handwashing facilities

3. Increase information media, you must wear a mask, keep a minimum distance of 1 meter, and wash your hands in all locations 


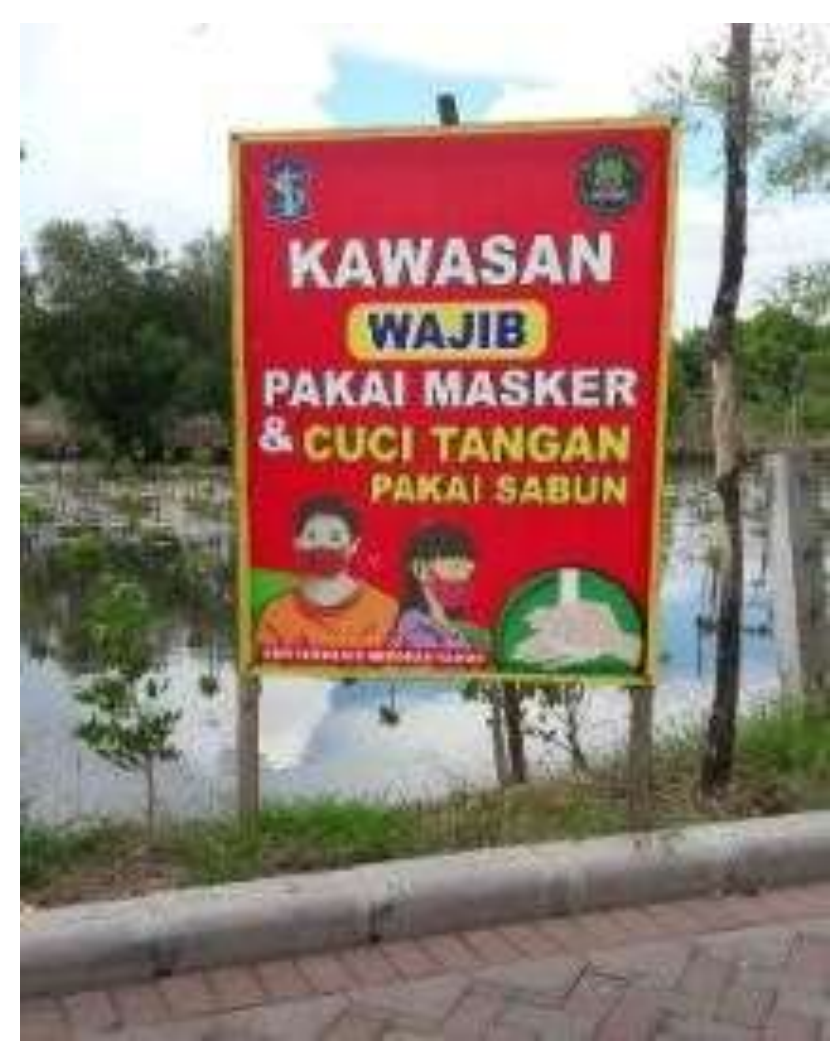

Figure 4. Information media

4. Notification of information regarding the prohibition of entry to tourist attraction locationsfor workers and visitors who have symptoms of fever, cough, runny nose, sore throat, and/or shortness of breath.

5. The policy of closing the Gunung Anyar ecotourism area for almost 3 months.

The closure for 3 months to reduce the spread of the coronavirus which is vulnerable to occur in tourist areas. Given that the visit to the Gunung Anyar ecotourismarea has reached up to 2000 visitors, closing it is anticipated.

6. Limitation of operating hours and also restrictions on the number of visitors In addition, the operational hours of mangrove ecotourism in Gunung Anyar and Wonorejo are also limited, opening from 09.00 to 14.00. Gunung Anyar Ecotourism willbe limited to 700-400 people because the capacity can be 2,000 visitors. He also implemented a one-way road for visitors while in the mangrove area.

7. Implementation of one gate system

The application of the one gate system concept is one of the managers' efforts so that visitors when entering and leaving do not meet, causing a crowd.

8. Application of health protocols

The application of health protocols for visitors is to require visitors to wear masks and before entering, their body temperature is checked using a thermal gun. 


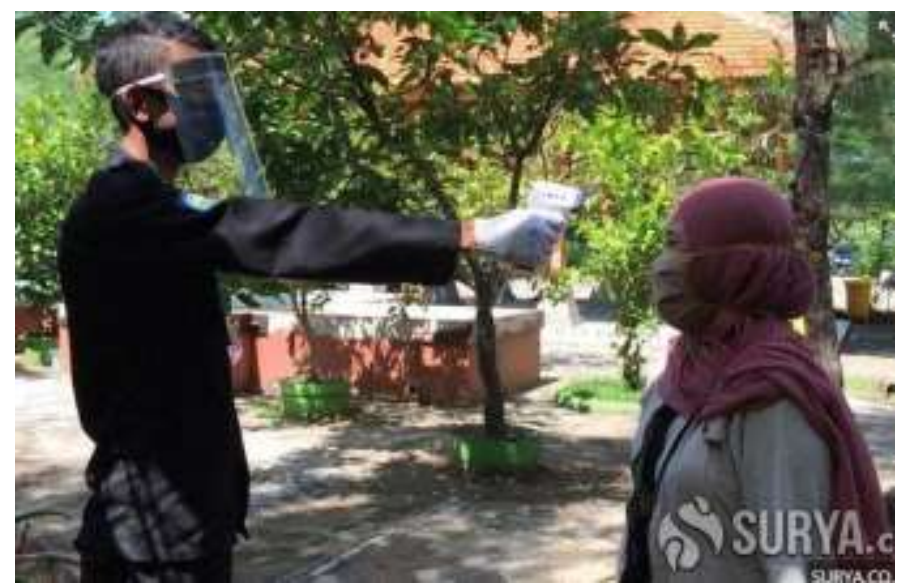

Figure 5. Application of health protocols

\section{Internal strategy (inward)}

1. Ensure that you are in good health before leaving for work at tourist attraction locations.

2. Increase endurance by consuming balanced nutrition, physical activity at least 30 minutes a day, and adequate rest by sleeping at least 7 hours, and avoiding risk factors fordisease.

The strategy carried out by the Gunung Anyar ecotourism manager is a strategy that is guided by the KMK regulation Number HK.01.07 / Menkes / 382/2020

\section{Conclusion}

Based on the results of the analysis carried out, Gunung Anyar ecotourism has implementeda health protocol following government directions which can be seen in KMK NumberHK.01.07 / Menkes / 382/2020. The strategy implemented is one of the efforts to limit the spread of coronavirus transmission and provide a sense of security for visitors to come to Gunung Anyar ecotourism.

\section{Acknowledgment}

I would like to thank LPPM UPN" Veteran" Jawa Timur for providing opportunities and funding for community service programs.

\section{References}

Candra, L. F. K., \& Rekha, A. (2020). The effects of pandemic era to tourism industry in Tangerang. Journal of Indonesian Tourism, Hospitality and Recreation, 3(2), 169-175.

Libus, L., \& Wahyudi. (2019). The implementation of mangrove policy on the East coast of Surabaya. Third International Conference on Sustainable Innovation 2019 - Humanity, Education and Social Sciences (IcoSIHESS 2019), Advances in Social Science, Education and Humanities Research, 353.

Sugiyono. (2017). Metode Penelitian Kuantitatif, Kualitatif, dan R\&D. Bandung: Alfabeta.

Trisbiantoro, D., Kusyairi, A., \& Mansur, S. (2020). Analisis potensi obyek ekowisata mangrove Gunung Anyar, Kelurahan Gunung Anyar Tambak, Kecamatan Gunung Anyar, Surabaya potencial analysis of ecotourism object mangrove GunungAnyar' Gunung Anyar District Surabaya. Jurnal Techno-Fish, 4(1), 1-10.

Umasugi, Sardi \& Suning. (2013). Studi pengembangan potensi objek wisata anyar mangrove(Wam) Di Kelurahan Gunung Anyar Tambak Surabaya. Jurnal Teknik WAKTU, 11, 115-120.

https://surabaya.tribunnews.com/2020/06/24/ekowisata-mangrove-wonorejo-surabaya- kembali-buka-protokol-kesehatan-diperketat. Diakses tanggal 7 Oktober 2020 https://www.kemenparekraf.go.id/ Protokol Kesehatan Bagi Masyarakat di Tempat dan Fasilitas Umum Dalam Rangka Pencegahan COVID-19. Diakses tanggal 10 Oktober 2020https://traveling.bisnis.com/ 